\title{
Assessment of Availability, Accessibility and Adequacy of Hostel Facilities in Nigerian Universities
}

\author{
Subair, S. 'Tayo*, Adeniyi, A. Omotosho \\ Department of Educational Management Faculty of Education Obafemi Awolowo University Ile-Ife, Nigeria \\ *Corresponding Author: Subair, S. 'Tayo, Department of Educational Management Faculty of \\ Education Obafemi Awolowo University Ile-Ife, Nigeria
}

\begin{abstract}
The study assessed availability of hostel accommodation facilities in Obafemi Awolowo University, Ile-Ife. It determined accessibility to the facilities and adequacy of the facilities for the intended users. These were with a view to providing information on the availability, accessibility and adequacy of current hostel accommodation in Nigerian Universities. The study adopted the descriptive survey research design. The population for the study consisted of all the 9,934 student residents in a university as at 2016/2017 academic session. A sample size of 993, representing $10 \%$ was drawn from the population. Proportionate sampling techniques was used to select the number of respondents from each hostel. A self-designed instrument titled Hostel Accommodation Questionnaire (HAQ) and On-the Spot-Assessment Observation Check List (OSAOCL) was used to elicit information on availability, accessibility and adequacy of hostel accommodation. Data collected were analysed using frequency counts and percentages. The results showed that hostel accommodation facilities were fairly available (43.1\%) and were also found to be fairly accessible (52.7\%). In terms of adequacy, the findings showed that available facilities were moderately adequate (41.4\%). The study concluded that hostel facilities were fairly available, accessible and moderately adequate; hence, there is the need to ensure more provision of hostels.
\end{abstract}

Key Words: Hostel Accommodation, Availability, Accessibility, Adequacy, Nigerian Universities

\section{INTRODUCTION}

Universities across the world and particularly in Nigeria are established essentially to advance knowledge through teaching and research, with the ultimate purpose of rendering services to the community apart from information dissemination. To attain these as perceived by Nigerian Government, the University College, Ibadan established 1944 was planned to accommodate between 800 and 1,000 students, but by 1950, the Institution had a student population of about 300. Similarly, other first generation universities such as Obafemi Awolowo University, (OAU) Ile-Ife, Ahmadu Bello University (ABU), Zaria and University of Lagos (UNILAG), Lagos were primarily residential, except the University of Nigeria (UNN), Nsukka (Alani, Okunola\&Subair, 2010). The Eliot Commission of 1945 and Ashby Commission of 1960 overtly emphasised the need to accommodate undergraduates on campus for educational, economic and social reasons, hence in Nigeria, every student admitted into the university expected a living space to be provided. In the last five decades and above, Nigerian universities have witnessed unprecedented increase in students' enrolment thereby making accommodation issue on campus to be a competition (Subair, 2008).

Obafemi Awolowo University, Ile-Ife is not left out of this situation. At inception, the Institution in 1962 had a student population of 244 students who were all accommodated. Going by the number of students on her enrolment which is 37,000 , the space available for accommodation can only comfortably take care of less than 11,000 (Students Affairs Division, OAU, 2017). Accommodation facilities, being a major welfare issue in Obafemi Awolowo University, has always been a major cause of students' crisis which had sometimes led to the closure of the University. Within the last 10 years, there had been at least four major documents on students' crisis, occasioned by agitations for improved welfare that led to school closure and subsequent disruption of academic calendars. Obafemi Awolowo University, Ile-Ife was closed down for academic activities and students sent home on $28^{\text {th }}$ February, 2007; $23^{\text {rd }}$ February, 2011;18th June, 2014and 3rd December, 2015 due to unrelenting demonstrations by students concerning welfare services (University Circulars Nos. RO.2/Vol. IV/500A, RO.2/Vol.VI/180, RO2/Vol. V/242). 
These closures had monumental negative effect on the Obafemi Awolowo University academic calendar and its functions. For instance, the school closure of $28^{\text {th }}$ February, 2007 disrupted the then on-going Harmattan Semester Examinations while that of 23rd February, 2011 led to the postponement of the University Matriculation. This is simply an indication that hostel accommodation in Obafemi Awolowo University, Ile-Ife is a major issue calling for investigation if its Mission which was stated as "...to create a conducive teaching and learning community for imparting skills, knowledge, behaviour and attitude; advance and protect the independence of academic enterprise; engender a sense of selfless public service and promote African culture and tradition" is to be fulfilled (Obafemi Awolowo University, 2012-2014 Calendar). One of the means of achieving the above is to provide accommodation facilities which would be adequate and accessible.

The emerging sustained growth at all stages of educational system has placed greater demands on those saddled with the administration and personnel services of educational system. The University as the highest level of schooling came into being for the promotion of learning by means of teaching and research, which necessitates that its beneficiaries must be accorded highest premium in terms of welfare services such as hostel accommodation facilities. In Nigeria, university hostel accommodations were observed to be inconvenient, irritating and dangerous to health with collapsed and outdated facilities (Alani, Okunola, \& Subair, 2010). Ike (1990) asserted that everything required to help university students achieve the most possible best results for their chosen academic pursuit should constitute students' welfare. To enable holistic development of the students as human beings, the quality of accommodation with the other amenities contained therein are regarded as key. Hence, provision of quality and readily available basic facilities, which must include toilets, running water, electricity, reading room, cafeteria, kitchenette and a recreation area are important in hostels meant for students.

A hostel is like a family of students with the superintendent (Hall Warden) as the head. Students develop a sense of friendship, learn the value of discipline, study with full concentration and inculcate neatness and healthful living. It has also been said that hostel enables students to study with full concentration and gets help from fellow or senior students. It is also a truism that availability of good accommodation facilitates students' learning in that students are within reasonable distance of academic and support facilities and the mere fact of residing with fellow students could inspire them to imbibe the culture of moral values. In Nigeria, there appears to be an acute shortage of hostel accommodation facilities. Ajayi and Ayodele (2001) explained that the standard of university academic programmes and availability of welfare facilities by the various universities is more often than not a determining factor for the standard of output when the students get to be on the job.

In the same vein, the National Universities Commission (2006) reported that findings have shown that academic and other facilities in the universities are not adequate, functioning, and accessible to students. This assertion makes one to become concerned on how many higher institutions were able to have successful accreditation of their courses. Perhaps the reasonIjaiya (2001) expressed concern about the poor quality of education of Nigerian students attributed to the poor facilities available to them. In addition, the disparity between the rate of student enrolment and availability of facilities such as accommodation and the attendant overcrowding which breeds unruly behaviour, unhygienic school environment and indecent behaviours, which is an antithesis to students' social expectations were also identified (Adeyemi\&Igbinewaka, 2000). The output of a category of students may not be totally isolated from the state of their hostel and its facilities. Therefore, the necessity for provision of an appropriate and befitting hostel accommodation facilities cannot be trivialised as it is a key to making students emotionally stable and mentally sound; these are necessary for them to excel academically and also make them have a sense of social security.

\section{LITERATURE REVIEW}

Since 1970s, hostel accommodation in Nigerian universities have become worrisome due to unprecedented students' enrolment. These situations have caused crisis and disruption of academic calendar, with its attendant consequences. There is therefore the need to assess the availability, accessibility, and adequacy of the state of these facilities. While the increase in population of students has been growing in geometric proportion, the provision of befitting hostel accommodation and adequate facilities has been growing in arithmetic progression. This has also led to the emergence of a set of students known as 'Squatters' in the hostels, while the officially allocated bed spaces are 
referred to as 'Bed Lords'. However, observations have shown that students' complaints in the past arose from inadequate welfare services particularly on issues bothering on hostel accommodation conditions and their maintenance; which has equally resulted into protests emanating from anxieties stirred by the combined effect of population explosion in the hostels and deteriorating facilities.

Research findings such as Subair (2008) and Alani, Okunola and Subair (2010) have shown that befitting accommodation facilities are central to conducive learning. Some of these include bed and beddings, electrical fittings and regular electricity supplies, functional plumbing materials, reading tables, chairs, window with mosquito nets, functional toilet facilities, good reading room, security coverage, cleaning services and internet facilities. Moreover, living in university accommodation has been said to afford the students the opportunity to learn how to be less dependent on family members. In addition, it has been observed that it is easier for students to mingle and have close bonds with fellow students. All these aid functional living in the community. The attendant effects of incessant school closures and disruption of academic calendar are poor self-esteems by the students residing in those hostels, who are equally exposed to health and environmental hazards. Thus, these make it pertinent to empirically examine the situation of hostel accommodations in Obafemi Awolowo University, a Nigerian university.

Existence and sufficiency of hostel facilities are the core factors in the identification of students' satisfaction. Therefore, the importance of the social environment in students' life cannot be overemphasised.Housing is one of the three basic needs of mankind. After the provision of food, it is most important factor for the physical survival of man. This is particularly true of a special category of individuals-students, especially those in tertiary institutions, who require good accommodation for proper assimilation of what they have been taught (Agbola, Olatubara\&Alabi, 2001). Housings' availability has been said to be highly essential to living in dignity and good quality of life, health, and general wellbeing. Over 100 million people throughout the world are said to still be without a home in spite of this seemingly inseparable link between good housing and health, while more than a billion live in houses that are not only insufficient but are also inimical to health (Godshall,2000).

From the review, tertiary institutions in Nigeria are seriously overcrowded. The fundamental cause of this issue is the expanding number of students being admitted, without a comparing increment in the quantity of hostel facilities (Agbola et al, 2001). In any case, it has been asserted that lodging affects the wellbeing, productivity, social conduct, fulfillment and general welfare of students. With this, it implies that lodging has effect on the performance and general wellbeing of its inhabitants. Learners require agreeable convenience for them to have a comfortable situation for their essential task of learning in their institutions (Osagie, 1993).

Nevertheless, original idea of students' housing was to provide a more conducive academic atmosphere for students. As a result, the first generation tertiary institutions built hostels, befitting the image of undergraduate students. Students' population then was within control (Egunyenga, 2009). Presently, the situation is opposite of what it used to be, as a result of incessant increase in number of prospective candidates seeking admission into Nigerian higher institutions. This has made students' housing to lose its principal reason of providing positive academic environment, that is, desirable education and social interaction. The joint impacts of these are expanded weight on utilities, for example, water, incessant breakdown of the sewage system and the unhygienic state of their living. This enormity of the circumstance in tertiary institutions required the need to carry out an evaluation of the existing facilities, in order to make suggestions for improvement.

\subsection{Statement of the Problem}

It is accepted that the basic needs of man in life is physiological, which includes food, clothing and housing. The significance of housing in man's life takes precedence except for food and clothing. That is, man looks for insulation from the environmental elements only after he has fulfilled the want of food and clothing. This postulation was reaffirmed by Maslow (1943) in his hierarchy of needs in which he postulated three principal needs essential to survival, which were food, clothing and shelter. The United Nations (2003) dichotomized between shelter and the concept of housing in that housing is widely accepted as being more than mere shelter, that is, it goes far beyond having a roof over one's head but rather contains a number of ancillary services and facilities, which link the individual concerned and his family to their community and their community to the region in which it grows and progresses. The fact that learners are expected to be in a sound state of mind to succeed in their 
academic undertakings which can guarantee not only physical protection but also a healthy social and behavioral stability underscore the need for convenient and effective students housing facility. In addition, the productivity of learners has been said may not be totally unconnected with their housing condition. The major challenge militating against housing has also been identified by Aluko (2011) to be geometric increase in the number of students without corresponding growth in the provision of hostels, required amenities and increasing environmental degradation. From all indications, hostels functionality depends seriously on ancillary service such as regular supply of electricity, portable water, cafeteria services, buttery, recreation/relaxation spot, laundry services and the likes.

No Nigerian university seem to be different in provision of this basic need of hostel accommodation. Current observations have shown that availability of water sometimes appear seasonal, electricity is irregular or high voltage electricity spoiling students' appliances, door-less rooms, damaged mattresses containing bed bugs, poor toilet facilities, congested laundry room, bathroom, kitchenettes and the likes

Students have been affected by the unstable electricity and shortage of portable water in their hostel. This has been said to have similarities with other business concerns where positive motivation of staff and positive disposition to clients with the view of having a common front which would engender unity of purpose among them are created. Obafemi Awolowo University is not in any way different in this situation. Observations have shown that water flow sometimes appears seasonal, high voltage of electricity spoiling students' appliances, door- less rooms with super cold feelings, damaged mattresses containing bed bugs, and poor toilet facilities. Interactions with some undergraduates on hostel matters many times become irritating and disgusting; with dirty comments and lamentations on situations they cannot help. There have been cases of scorpion sting and snake bites within hostel environments, rooms, bathrooms and toilets.

The emergence of increased enrolments in Nigerian Universities can be traced to late 1970s, but it reached appreciable level in mid 1980s which was when Federal Government also had to stop the school feeding programme in Nigerian Universities due to paucity of funds to meet the needs of students. The emergence of squatters in the Obafemi Awolowo University hostels gradually started becoming significant, until it became an issue in the early 90 s, which the university administration has not been able to address due to fear of students' unrest until 2017 when this study was being carried out. All these motivated this study.

\subsection{Research Questions}

The following questions were raised to guide the study:

1. How available are hostel accommodation facilities (bed spaces, beds and beddings, toilet facilities, car parks and reading rooms, electrical, plumbing, and kitchenette)?

2. How accessible are the facilities for the students?

3. How adequate are the facilities for intended users?

\section{MeThOdOLOGY}

The study employed descriptive research design because it enabled the researchers to describe and explain the existing situation in the students' hostel using quantitative approach. The population of this study comprised 9,934 students residing in OAU hostels as at 2016/2017 academic session. The hostels are Awolowo, Fajuyi, Angola, ETF, Mozambique, Post Graduate, Akintola, Moremi and Alumni (situated within OAU, Ile-Ife). The sample size for the study consisted of 993 students officially provided with bed spaces in the hostels. Proportionate sampling procedure was used to determine the number of students used in each hall of residence. A minimum of $10 \%$ students allocated bed spaces in each hostel was selected for the study. Convenience sampling technique was used in administering the instrument. Out of the 1,033 administered, 667 were returned, which is $63.9 \%$. This was because of the high mobility of students. Two self-designed instruments were used to gather data for the study. This was Hostel Accommodation Questionnaire (HAQ). In addition, the Researchers designed On-the-Spot Assessment Observation Checklist (OSAOCL). The HAQ consisted of two sections; the first section consisted of demographic information of the respondents while the second section contained 25 items that were used to elicit information from the hostel residents. The OSAOCL which is an Observation Checklist contained two sections; the first section 
consisted of the demographic data of hostel, while the second section contained 23 items which were completed by the researchers on direct observation basis in the halls of residence. The developed instrument was validated and scrutinised to ensure that they contain no ambiguity and to meet both face and content validity. The reliability was ensured by subjecting the instrument to test and retest reliability method in a pilot study on 100 respondents at the University of Lagos (Moremi Hall (Female) and Biobaku Hall (Male). The results obtained showed reliability co-efficient of 0.70 which indicated that the instrument was reliable. The primary data collected from the Halls of residence were sorted in order to remove irrelevant responses. Frequency distribution and percentages were used to answer the research questions.

\section{ReSUlts}

Research Question 1: How available are hostel accommodation facilities? To answer this question, respondents' responses were analysed using frequency count and percentage. The results are presented in Table 1.

Table1. Availability of Hostel Accommodation Facilities

\begin{tabular}{|l|l|l|l|l|}
\hline S/N & Facilities & Very Available (\%) & Fairly Available (\%) & Not Available (\%) \\
\hline 1. & Bed & $352(52.8)$ & $209(31.4)$ & $106(15.8)$ \\
\hline 2. & Beddings & $248(37.2)$ & $170(25.5)$ & $249(37.3)$ \\
\hline 3. & Wardrobe & $393(58.9)$ & $197(29.5)$ & $77(11.5)$ \\
\hline 4. & Electrical fittings & $205(30.7)$ & $322(48.3)$ & $140(21.0)$ \\
\hline 5. & Kitchenette & $241(36.1)$ & $256(38.4)$ & $170(25.5)$ \\
\hline 6. & Electricity Supply & $360(54.0)$ & $205(30.7)$ & $102(15.3)$ \\
\hline 7. & Water supply & $281(42.1)$ & $270(40.5)$ & $116(17.4)$ \\
\hline 8. & Cafeteria & $107(16.0)$ & $412(61.8)$ & $148(22.2)$ \\
\hline 9. & Reading Room & $237(35.5)$ & $369(55.3)$ & $61(9.1)$ \\
\hline 10. & Common Room & $258(38.7)$ & $284(42.6)$ & $125(18.7)$ \\
\hline 11. & Plumbing fittings & $181(27.1)$ & $271(40.6)$ & $215(32.2)$ \\
\hline 12. & Waste disposal & $254(38.1)$ & $290(43.5)$ & $123(18.4)$ \\
\hline 13. & Bathroom & $294(44.1)$ & $288(43.2)$ & $85(12.7)$ \\
\hline 14. & Toilets & $226(33.9)$ & $406(60.9)$ & $35(5.2)$ \\
\hline 15. & Book shelf & $169(25.3)$ & $330(49.5)$ & $168(25.2)$ \\
\hline 16. & Fire safety equipment & $63(9.4)$ & $227(34.0)$ & $377(56.5)$ \\
\hline 17. & Parking lots & $248(37.2)$ & $332(49.8)$ & $87(13.0)$ \\
\hline 18. & Internet & $183(27.4)$ & $313(46.9)$ & $171(25.6)$ \\
\hline 19. & Reading Chairs and Tables & $183(27.4)$ & $233(34.9)$ & $251(37.7)$ \\
\hline 20. & Cleaning services & $214(32.1)$ & $345(51.7)$ & $108(16.2)$ \\
\hline 21. & Mini/Super market & $114(17.1)$ & $468(70.2)$ & $85(12.7)$ \\
\hline 22. & Sporting & $37(5.5)$ & $304(45.6)$ & $326(48.9)$ \\
\hline 23. & Mobile network & $85(12.7)$ & $401(60.1)$ & $181(27.1)$ \\
\hline 24. & Automated Teller Machine & $77(11.5)$ & $125(18.7)$ & $465(69.7)$ \\
\hline 25. & Close Circuit Television & $22(3.3)$ & $161(24.1)$ & $484(72.6)$ \\
\hline & Average Percentage & $\mathbf{3 0 . 2 \%}$ & $\mathbf{4 3 . 1 \%}$ & $\mathbf{2 6 . 7 \%}$ \\
\hline
\end{tabular}

Table 1shows the hostel accommodation facilities that were available in Obafemi Awolowo University (OAU), Ile-Ife. The hostel accommodation facilities that were very available include wardrobe $(58.9 \%)$, electricity supply $(54 \%)$, and bed $(52 \%)$. The respondents also identified other accommodation facilities that were fairly available to include, mini/super market $(70.2 \%)$, cafeteria $(61.8 \%)$, toilets $(60.9 \%)$, mobile network $(60.1 \%)$, reading room $(55.3 \%)$, cleaning services $(51.7 \%)$, parking lots (49.8\%), book shelf (49.5\%), electrical fittings (48.3\%), internet (46.9\%), sporting (48.9\%), waste disposal (43.5\%), common room (42.6\%), plumbing fittings (40.6\%) and water supply (40.5\%). However, some accommodation facilities such as CCTV (72.6\%), ATM (69.7\%) and fire safety equipment $(56.5 \%)$ were not available, while reading chairs, tables and beddings facilities were not available according to the respondents. It can therefore be said that hostel accommodation facilities are fairly available on campus with $43.1 \%$ as against $30.2 \%$ for much available and $26.7 \%$ for Not Available. In essence, $43.1 \%$ of the respondents informed that they were aware of available hostel accommodation facilities on campus and that many of these hostel accommodation facilities are fairly available. 
Research Question 2: How accessible are students to hostel accommodation facilities? To answer this question, respondents' responses were analysed using percentage. The results are presented in Table 2.

Table2. Accessibility to Hostel Accommodation Facilities

\begin{tabular}{|l|l|c|l|l|}
\hline S/N & Facilities & Very Accessible (\%) & Fairly Accessible (\%) & Not Accessible (\%) \\
\hline 1. & Bed & $276(41.4)$ & $317(47.5)$ & $74(11.1)$ \\
\hline 2. & Beddings & $158(23.7)$ & $357(53.5)$ & $152(22.8)$ \\
\hline 3. & Wardrobe & $299(44.8)$ & $310(46.5)$ & $58(8.7)$ \\
\hline 4. & Electrical fittings & $201(30.1)$ & $350(52.5)$ & $116(17.4)$ \\
\hline 5. & Kitchenette & $128(19.2)$ & $291(43.6)$ & $248(37.2)$ \\
\hline 6. & Electricity Supply & $251(37.6)$ & $342(51.3)$ & $74(11.1)$ \\
\hline 7. & Water supply & $152(22.8)$ & $456(68.4)$ & $59(8.8)$ \\
\hline 8. & Cafeteria & $62(9.3)$ & $442(66.3)$ & $163(24.4)$ \\
\hline 9. & Reading Room & $125(18.7)$ & $379(56.8)$ & $163(24.4)$ \\
\hline 10. & Common Room & $276(41.4)$ & $334(50.1)$ & $57(8.5)$ \\
\hline 11. & Plumbing fittings & $116(17.4)$ & $395(59.2)$ & $156(23.4)$ \\
\hline 12. & Waste disposal & $156(23.4)$ & $348(52.2)$ & $163(24.4)$ \\
\hline 13. & Bathroom & $121(18.1)$ & $443(66.4)$ & $103(15.4)$ \\
\hline 14. & Toilets & $107(16.0)$ & $427(64.0)$ & $133(19.9)$ \\
\hline 15. & Book shelf & $73(10.9)$ & $434(65.1)$ & $160(24.0)$ \\
\hline 16. & Fire safety equipment & $78(11.7)$ & $300(45.0)$ & $289(43.3)$ \\
\hline 17. & Parking lots & $227(34.0)$ & $332(49.8)$ & $108(16.2)$ \\
\hline 18. & Internet & $124(18.6)$ & $316(47.4)$ & $227(34.0)$ \\
\hline 19. & Reading Chairs and Tables & $126(18.9)$ & $366(54.9)$ & $175(26.2)$ \\
\hline 20. & Cleaning services & $143(21.4)$ & $379(56.8)$ & $145(21.7)$ \\
\hline 21. & Mini/Super market & $181(27.1)$ & $379(56.8)$ & $107(16.0)$ \\
\hline 22. & Sporting & $89(13.3)$ & $297(44.5)$ & $281(42.1)$ \\
\hline 23. & Mobile network & $91(13.6)$ & $409(61.3)$ & $167(25.0)$ \\
\hline 24. & ATM machine & $50(7.5)$ & $127(19.0)$ & $490(73.5)$ \\
\hline 25. & CCTV & $20(3.0)$ & $158(23.7)$ & $489(73.3)$ \\
\hline & Average Percentage & $\mathbf{2 1 . 7 \%}$ & $\mathbf{5 2 . 1 \%}$ & $\mathbf{2 6 . 1 \%}$ \\
\hline
\end{tabular}

Table 2 shows the responses of the respondents to accessibility of available hostel accommodation facilities in Obafemi Awolowo University. The respondents informed that water supply $(68.4 \%)$, bathroom $(66.4 \%)$, cafeteria $(66.3 \%)$, book shelf $(65.1 \%)$, toilets $(64.0 \%)$, mobile network $(61.3 \%)$, plumbing fittings $(59.2 \%)$, mini/super market, reading room and cleaning services $(56.8 \%)$ facilities were fairly accessible. Considering the other available hostel accommodation facilities identified by the respondents which include reading chairs and tables $(54.9 \%)$, beddings $(53.5 \%)$, waste disposal (52.2\%), electrical fittings (52.5\%), electricity supply (52.3\%), Common Room (50.1\%), parking lots $(49.8 \%)$, bed $(47.5 \%)$, internet $(47.4 \%)$, wardrobe $(46.5 \%)$, fire safety equipment $(45.0 \%)$, sporting (44.5\%) and kitchenette (43.6\%) facilities were also fairly accessible. However, some facilities such as ATM (73.5\%) and CCTV (73.3\%) were not accessible by the students. It can therefore be established that hostel accommodation facilities are fairly accessible on campus with $52.1 \%$ as against $21.7 \%$ for much Accessible and $26.1 \%$ for Not Available.

Research Question 3: How adequate are the facilities for intended users? To answer this question, respondents' responses were analysed using percentage. The results are presented in Table 3.

Table3. Adequacy of Hostel Accommodation Facilities

\begin{tabular}{|l|l|l|l|l|}
\hline S/N & Facilities & High (\%) & Moderate (\%) & Low (\%) \\
\hline 1. & Bed & $261(39.1)$ & $265(39.7)$ & $141(21.1)$ \\
\hline 2. & Beddings & $182(27.3)$ & $211(31.6)$ & $274(41.1)$ \\
\hline 3. & Wardrobe & $257(38.5)$ & $247(37.0)$ & $163(24.4)$ \\
\hline 4. & Electrical fittings & $180(27.0)$ & $232(34.8)$ & $255(38.2)$ \\
\hline 5. & Kitchenette & $115(17.2)$ & $238(35.7)$ & $314(47.1)$ \\
\hline 6. & Electricity Supply & $250(37.5)$ & $237(35.5)$ & $180(27.0)$ \\
\hline 7. & Water supply & $162(24.3)$ & $299(44.8)$ & $206(30.9)$ \\
\hline 8. & Cafeteria & $88(13.2)$ & $230(34.5)$ & $349(52.3)$ \\
\hline 9. & Reading Room & $111(16.6)$ & $341(51.1)$ & $215(32.2)$ \\
\hline
\end{tabular}




\begin{tabular}{|c|c|c|c|c|}
\hline 10. & Common Room & $189(28.3)$ & $322(48.3)$ & $156(23.4)$ \\
\hline 11. & Plumbing fittings & $129(19.3)$ & $238(35.7)$ & $300(45.0)$ \\
\hline 12. & Waste disposal & $215(32.2)$ & $145(21.7)$ & $307(46.0)$ \\
\hline 13. & Bathroom & $134(20.1)$ & $286(42.9)$ & $247(37.0)$ \\
\hline 14. & Toilets & $131(19.6)$ & $272(40.8)$ & $264(39.6)$ \\
\hline 15. & Book shelf & $112(16.8)$ & $308(46.2)$ & $247(37.0)$ \\
\hline 16. & Fire safety equipment & $63(9.4)$ & $263(39.4)$ & $341(51.1)$ \\
\hline 17. & Parking lots & $162(24.3)$ & $406(60.9)$ & $99(14.8)$ \\
\hline 18. & Internet & $130(19.5)$ & $331(49.6)$ & $206(30.9)$ \\
\hline 19. & Reading Chairs and Tables & $130(19.5)$ & $268(40.2)$ & $269(40.3)$ \\
\hline 20. & Cleaning services & $127(19.0)$ & $421(63.1)$ & $119(17.8)$ \\
\hline 21. & Mini/Super market & $72(10.8)$ & $474(71.1)$ & $121(18.1)$ \\
\hline 22. & Sporting & $41(6.1)$ & $282(42.3)$ & $344(51.6)$ \\
\hline 23. & Mobile network & $41(6.1)$ & $379(56.8)$ & $247(37.0)$ \\
\hline 24. & ATM machine & $33(4.9)$ & $91(11.6)$ & $543(81.4)$ \\
\hline \multirow[t]{2}{*}{25.} & CCTV & $5(0.7)$ & $123(8.4)$ & $539(0.8)$ \\
\hline & Average Percentage & $19.91 \%$ & $41.4 \%$ & $38.6 \%$ \\
\hline
\end{tabular}

Table 3 shows the adequacies of hostel accommodation facilities as attested to by respondents. It was observed that wardrobe (38.5\%), electricity supply $(37.5 \%)$ are high in terms of adequacy while hostel facilities such as mini/super market $(71.1 \%)$, cleaning services $(63.1 \%)$, parking lots $(60.9 \%)$, mobile network $(56.8 \%)$, reading room $(51.1 \%)$, internet $(49.6 \%)$, common room $(48.3 \%)$, book shelf $(46.2 \%)$, water supply $(44.8 \%)$, bathroom $(42.9 \%)$, toilets $(40.8 \%)$ and bed $(39.7 \%)$ are moderate in terms of adequacy. The results also show that hostel accommodation facilities such as ATM machine $(81.4 \%)$, CCTV $(80.8 \%)$, cafeteria $(52.3 \%)$, sporting $(51.6 \%)$, fire safety equipment $(51.1 \%)$, kitchenette $(47.1 \%)$, waste disposal (46.0\%), plumbing fittings $(45.0 \%)$, beddings $(41.1 \%)$, reading chairs and tables $(40.3 \%)$ are low in terms of adequacy.

Based on the above findings, it can be affirmed that the available hostel accommodation facilities in Obafemi Awolowo University is moderately adequate with $41.4 \%$, as against $19.91 \%$ for Low and $38.6 \%$ Highly Adequate.

\subsection{Discussion of Findings}

On availability of hostel accommodation facilities, this study showed that hostel accommodation facilities were fairly available on campus with $43.1 \%$. The fact that the level of availability is fair indicated that the existing facilities did not meet fully the needs of the students. In essence, there is a gap to be filled. The finding is also in line with Ezukwu (1999) and Onyegiri, 2004 who asserted that hostel accommodation facilities must be available and satisfy the need of the students.

To research question two, the findings showed that $52.1 \%$ of the respondents affirmed that the hostel facilities were fairly accessible. This indicated that even the fairly available facilities were not fully accessible, possibly due to some facilities being locked up as at the time of this study as observed by the researcher. Such were the unusable toilets, birth rooms with blocked pipes and so on. It was observed that some kitchenettes meant for students have been converted to commercial dry cleaning use, hair salon and photocopying centres, to mention just a few. This finding is in line with Adegbile (1987) and Adelaja (1992) who opined that a portion of the current furniture beds in student hostels has been expelled with the end goal to give space to extra twofold bunks. The greater part of the couple of offices that directly exist in Nigerian educational institutions are the worked in-type. Subsequently and that most students need to find somewhere else to read due to the unconducive nature of their hostels. Ezenwa (2007) also said that in some universities, the female students had to wake up as early as 4:00 am to take their bath in the open places within the hostel premises.

In addition, findings on research question three on adequacy of the facilities for intended users showed that the facilities were only moderately adequate with $41.4 \%$. The implication of this is that more often than not, students have had to line up to use bathroom, toilets and to also fetch water from the water tanks. All these prevent students from maximising their times for their academic work and also have the potentials of stirring up a sense of resentment from the students which often lead to student's unrest with its attendant negative implications. This is in line with the findings of Onyegiri (2004), Akpan (2000) and Okoh (2004) who said that lack of adequate hostel accommodation in the tertiary institutions have resulted into resale of bed space by students to their frustrated peers thereby exploiting them unnecessarily. 


\section{CONCLUSION}

This study has established that the hostel accommodation facilities in Obafemi Awolowo University, Ile-Ife are moderately available, fairly accessible, and moderately adequate. This shows clear indication that there is a gap between the ideal state of the facilities and what was on ground. Consequently, there is room for improvement to ensure that the students derive maximum benefits from residing on the university campus. The provision of which would reduce the incidence of students' agitation for improved welfare services which more often than not led to school closure and disruption of university academic calendar. The University should therefore pay attention to the issue of students' welfare as they are statutorily members of the University Community and also the key essence of the establishment of the University.

\section{RECOMMENDATIONS}

Sequel to the findings of this study, it is recommended that Obafemi Awolowo University Administration should endeavour to improve on the provision of accommodation facilities so as to make them highly accessible and adequate. The University administration should formulate an accommodation policy that would ensure that more students have access to hostel accommodation in the University by constructing more hostels, and also find ways of effecting a ban on squatting in the hostels so as to reduce pressure on the limited available facilities. Also, other facilities such as ATM and CCTV Camera, should be made available in the student hostels to ensure adequate security. Also, students would have an easy access to cash if ATM is within their hostels.

\section{REFERENCES}

[1] Adeyemi J. K, \&Igbineweka, V. O (2000). Sitting space utilization in Nigerian universities: A case study of the University of Benin. Journal of Teachers Education. Teach. 4(1): 12-23.

[2] Abramson, P. (2009). Downsizing residence halls: space and costs, Living on Campus, College Housing Report.12.(5), 20-27

[3] Abramson, P. (2010). Green and growing: sustainability and amenities are increasing in new residence hall projects", Living on Campus, College Housing Report, 13. (5), 20- 30.

[4] Adegbile, M. B. O. (1987): Student reaction in four halls of residence. A Seminar Paper Submitted to the Department of Architecture. Obafemi Awolowo University, Ile-Ife.

[5] Retrieved April, 2017 file:///C:/Users/ADENIYI/AppData/Local/Temp/26068-28746-1-PB.pdf

[6] Adelaja, A. A. (1992): Student housing problem. A Seminar Paper Presented to the Department of Architecture, Obafemi Awolowo University, Ile-Ife.

[7] Adeniyi, A. O. (2018) Hostel accommodation and facilities management approaches in Obafemi Awolowo University, Ile-Ife. Unpublished M.A Thesis, Obafemi Awolowo University, Ile-Ife, Nigeria.

[8] Agbola, T., Olatubara, C. O. \&Alabi, M. (2001). Student On- Campus Housing at Bursting Point: A Cas e Study of University of Ibadan, Occasional Publication; .14, 7-10.

[9] Ajayi, I. A. \&Ayodele, J. B (2001). Introduction to educational planning, administration and supervision. Ado-Ekiti. YemiPrints and Publishing Services.

[10] Akpan, P. A. (2000). Housing conditions and environmental quality in IkotEkpene, Nigeria

[11] African Journal of Social and Policy Studies, 1, 1-7.

[12] Alani, R. A, Okunola, P. O \&Subair, S. O (2010). Situation analysis of students' welfare services in universities in South-western Nigeria: Implications for students' personnel management practice. USChina Education Review, 7(10); 42- 50.

[13] Chukwu, J. (2001). Problems of students hostel accommodation in higher educational institutions: A Case study of the University of Nigeria, Nsukka. In A.Y. Akubue, \& D. Enyi (eds.), Crises and challenges in higher education in developing countries. Ibadan: Wisdom Publishers.

[14] Clark, B. \&Meave, G. (eds) (1992). The encyclopedia of higher education, analytical perspectives. Oxford: Pergamon Press.

[15] Curley, P. (2003), Residence halls: Making campus a home, American School \& University, 75, (12), 245 256.

[16] Egunyenga, E. J. (2009). Room-mate Conflicts in Nigerian Universities: Causes and Management Strategies, Department of Educational Administration and Policy Studies, Delta University, Abraka, Nigeria.

[17] Ezenwa, N. (2007). Private-public partnership in the management of student hostels in the Nigerian Universities. (An Unpublished M.ED)., University of Ibadan, Ibadan. 
[18] Ezukwu, O. (1999). Issues in hostel management in the Nigerian tertiary institution. Unpublished M.ED. Project University of Nigeria, Nzuka.

[19] Federal Government of Nigeria. (1989). Approved minimum academic standard in science for the Nigerian Universities Commission (NUC). Lagos, Nigeria: FGN.

[20] Federal Republic of Nigeria. (2004). National policy on education (4 ${ }^{\text {th }}$ edition) Lagos: NERDC.

[21] Godshall, R. (2000). Creating Communities. American School and University, 72(12), 150-155.

[22] Hornby, A. (2000). Advanced Learners Dictionary of Current English. Oxford: Oxford University Press.

[23] Ijaiya, Y. (2001). From quality control to quality assurance: A panacea for quality education in Nigerian Schools. In N.A. Nwagwu, E.T. Ehiametalor, M.A Ogunu and M. Nwadiani (Eds). Current issues in educational management in Nigeria: A publication of the Nigerian Association for Educational Administration and Planning. Benin City.

[24] Ike, C. (1990). Management of Nigerian Universities in the 90's: Students Welfare and Discipline, Proceedings of the 14th Annual Seminar of Committee of Vice-Chancellors, Benin city, Nigeria: University of Benin.

[25] National University Commission (2006). Ban on Admission into more programmes with denied accreditation, Monday Memo, May 4 (18). Okebukola.

[26] Ojogwu, C. N. \&Alutu, A.N.G (2009). Analysis of the learning environment of university students in Nigerian Journal of Social Science, 19(1), 69-73.

[27] Okoh, J. (2004). Sustainable funding of higher education inter-country analysis. The Colloquium.

[28] Onibokun, A. G. (1985), Cited in Akinola, S. R. (1998): The Pattern of Housing Quality in Osogbo. Journal of Environmental Design and Management, 1, (1\&2), 109-110.

[29] Onyegiri I. (2004)Foundations/management-of-students-hostel-accommodation-problems-in-federalcolleges-of-educationin-south-eastern-nigeria. https://www.projectslib.com/projects/education/educationn al-

[30] Osagie, R. O. (1993). Dropout in the University of Benin. Unpublished M.Ed. Dissertation, Benin: Faculty of Education, University of Benin.

[31] Subair, S. 'Tayo (2008) Infrastructure, welfare services and students' perceived motivation to learning in universities in south-west Nigeria. Unpublished Ph.D. Thesis, University of Lagos.

\section{AUTHORS' BIOGRAPHY}

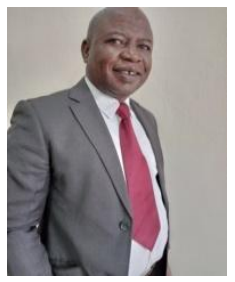

Subair Sikiru Omotayo, is a Lecturer in the Department of Educational Management, Faculty of Education, Obafemi Awolowo University, Ile-Ife, Nigeria. His research area is Institutional Administration and Personnel Management. He has gotten over a decade teaching experience in the University. He has supervised many undergraduates' long essays, Master degree thesis, and Doctoral degree dissertations. He is currently the Vice-Dean, Faculty of Education. He is a Nigerian.

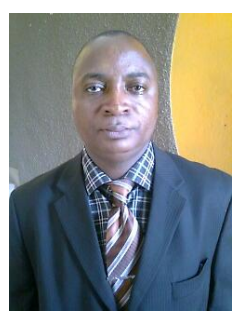

Mr. Anthony Omotosho Adeniyi, is a Professional University Administrator at Obafemi Awolowo University Ile-Ife. He is the Faculty Secretary for the Faculty of Pharmacy of the University. He has Master Degree in Public Administration and Master Degree in Higher Education Administration. He is married with children.

Citation: Subair, S. 'Tayo, Adeniyi, A. Omotosho. "Assessment of Availability, Accessibility and Adequacy of Hostel Facilities in Nigerian Universities" International Journal of Humanities Social Sciences and Education (IJHSSE), vol 8, no. 7, 2021, pp. 17-25. doi: https://doi.org/10.20431/2349-0381.0807003.

Copyright: (C) 2021 Authors. This is an open-access article distributed under the terms of the Creative Commons Attribution License, which permits unrestricted use, distribution, and reproduction in any medium, provided the original author and source are credited. 